بررسى ايزوزيمهاى استراز و يراكسيداز در جمعيتهاى بومى و اصلاح شده يونجه و ارتباط آنها با

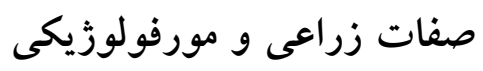

مريم احمدى'، مصطفى وليزاده ‘."، محمود تورجهى'، محمد مقدم واحد' و حسين محمد زاده جلالى' ا - دانش آموخته كارشناسى ارشد، كروه بهنزادى و بيوتكنولوزى، دانشكده كشاورزى دانشكاه تبريز، تبريز

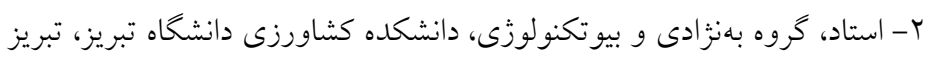

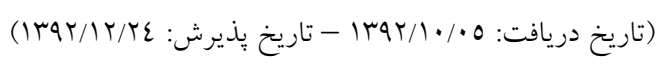

جكيده

بلمنظور ارزيابى تنوع زنتيكى ارقام اصلاح شده و بومى يونجه، rا رقم يونجه شامل بنج رقم اصلاح شده (كايسارى، كدى،

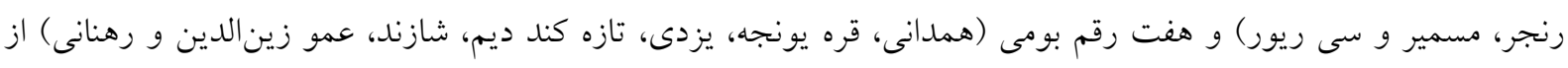

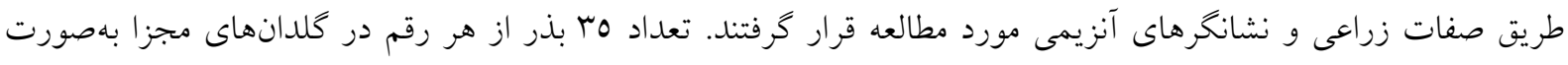

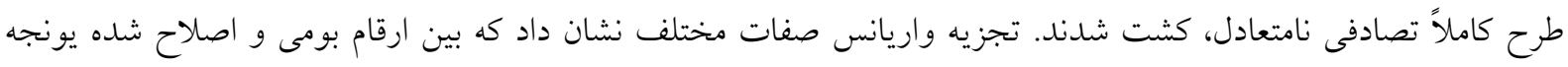

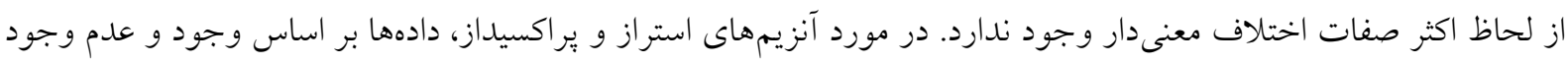

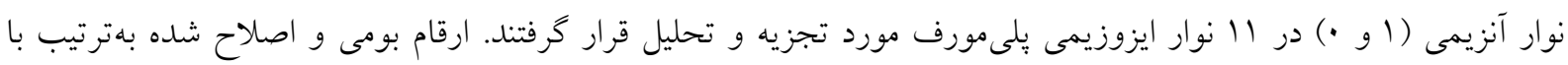

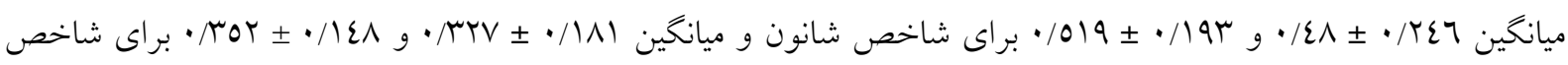

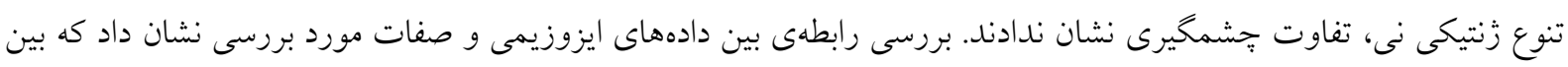

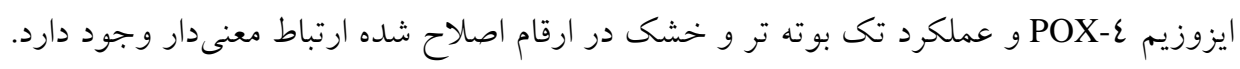

وازگًان كليدى: يونجه، تنوع زنتيكى، نشانكرهاى ايزوزيمى، جندشكلى 
(زنهاى ساختارى) بيشتر از اغلب نشانخرهاى مبتنى بر

است (Corts and Martinez, 2000). از ايزوزيمها مىتوان براى مطالعه زرميلاسم گياهان استفاده كرد. تنوع زنتيكى يا فاصله زنتيكى از طريق بررسى تنوع آلوزايمى قابل اندازه گيرى است و تعيين و تشخيص يك جمعيت يا رقم زراعى، شناسايى اختلاف زنتيكى افراد، تعيين روابط زنتيكى در داخل كونهها، تجزيه و تحليل الكوهاى مهاجرتى يكى كونه از مراكز اوليه از جمله موارد عمده استفاده از ايزوزيمها در مطالعات تنوع زنتيكى است Quiros, ( ) (Labdi et al., 1996) 1980) از الكتروفورز آنزيمهاى استراز، يراكسيداز، اسيدفسفاتاز و لوسين آمينويتيداز با زل نشاسته براى شناسايى زنوتيٍِهاى يونجه استفاده كرد و گزارش نمود كه سه آنزيم اول در برى بوتههاى مادرى الخوى نواربندى متفاوت و قابل شناسايى ايجاد مى كنند. وى اين روش را در ساير كونهاى يونجه نيز مورد استفاده قرار داد. كالجوند و جاسكا (Kaljund and Jaaska, 2010) نشانگرهاى آلوزايمى مولكولى سه ايزوزيم جند شكل را براى تخمين تنوع زنتيكى وابسته به اندازه جمعيت و درجه دورى، بين نتاج حاصل از بذر در جمعيتهاى يونجه گونه M. sativa نتيجه رسيدند كه حتى كو جكترين جمعيت تنوع زنتيكى بالايى در حدود جمعيتى كه صد بار از آن بزرگتر بود را داشت. همجنين تفاوت زنتيكى جمعيتها به استثناى يك جمعيت دور، در دو گروه اصلى با موقعيت جغرافيايى جمعيتها مرتبط بود. هدف از اين بيزوهش بررسى ميزان تنوع در جمعيتهاى بومى و اصلاح شده يونجه از طريق نشانخرهاى ايزوزيمى و ارتباط اين نشانخرها با صفات زراعى و مورفولوزيكى بود.

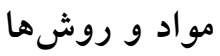

آزمايش در سال 91/1 در ايستخاه تحقيقات دانشكده كشاورزى دانشخاه تبريز در اراضى كركج واقع در دوازده كيلومترى شرق تبريز اجرا گرديد. مواد گياهى شامل ينج رقم اصلاح شده (كايسارى، كدى، رنجر، مسمير و سى

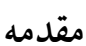

يونجه (Medicago sativa L.) يكى از مهمترين كياهان علوفهاى در دنيا محسوب مىشود و عقيده بر اين است كه از نواحى شمال غربى ايران، جنوب قفقاز، شمال Michaud et ( شرقى تركيه و تركمنستان منشأ گرفته باشد (al., 1988 . يونجه با دارا بودن ساختار زنتيكى

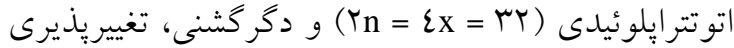
زيادى در سطح زنوم دارد. وجود تغييريذيرى زياد، شناسايى واريتههاى مختلف را توسط صفات زراعى و Corts and Martinez, ) مورفولوزيكى مشكل مىسازد 2000). مطالعات سيتولوزيكى نشان ميدهد كه يونجه ميوز منظم با 17 بيىولنت و تعداد كمى مولتىوالنت دارد (McCoy and Bingham, 1988). منابع زنتيكى، تأمين كننده زنهاى با ارزشى هستند كه در صورت بهرهبردارى صحيح از آنها مىتوان ارقام جديد و مطلوب را توليد كرد. در واقع تنوع زنتيكى بيشنياز گزينش در برنامههاى بهنزادى براى بهبود صفات و توليد ارقام جديد و ساز گار مىباشد (Oleson, 1994; Clegg, 1997). در جمعيتهاى طبيعى، جهشهاى مكرر در يك زن باعث ايجاد تنوع مىشوند (Zeidler, 2000). براى ارزيابى تنوع زنتيكى،

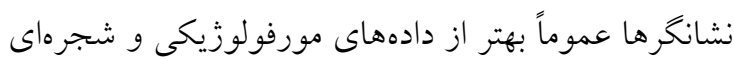
هستند و تنوع زنتيكى معمولاً توسط فاصله زنتيكى يا تشابه زنتيكى اندازهكيرى مىشود ( Lamkey and Lee, 1993). روش هاى كلاسيك اصلاحنباتات بهتدريج تنوع زنتيكى را كاهش مىدهند و اين كاهش مىتواند براى آينده برنامههاى اصلاحى خطر آفرين باشد ( Corts and Martinez, 2000 . نشانگرهاى مولكولى در زمينه مطالعه تنوع زنتيكى و روابط بين زرميهاسمها بسيار مفيد هستند و مىتوانند براى شناسايى جمعيتهاى مناطق مختلف مورد استفاده واقع شوند (Veronesi et al., 2003). امروزه نشانكرهاى مولكولى متعددى براى برآورد تنوع زنتيكى وجود دارد ولى الكتروفورز يروتئينها همواره روشى ساده و مرسوم براى برآورد تنوع زنتيكى در كياهان به شمار

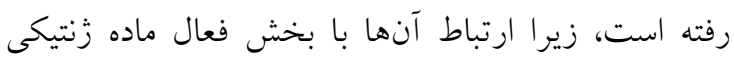


Soltis ) رنخ آميزى زل از روش كار سولتيس و سولتيس

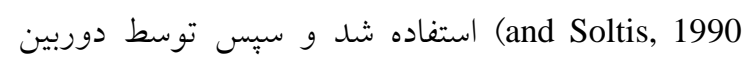
ديجيتالى از زلها عكسبردارى شد. الكوهاى آنزيمى در جمعيتهاى يونجه بهصورت وجود نوار بروتئينى (امتياز

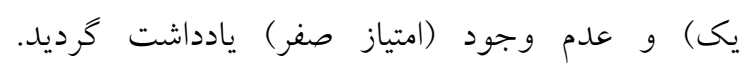

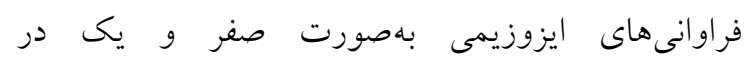

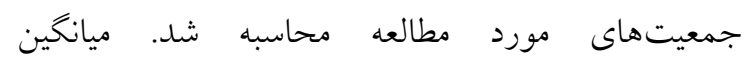
هتروزيخوتى مورد انتظار با فرض تعادل (He) به شرح زئه

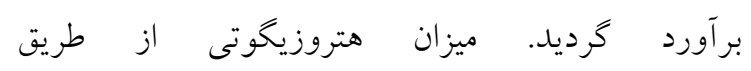

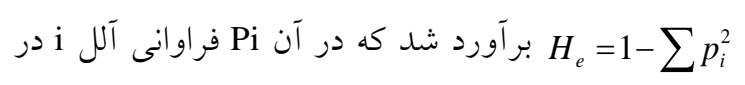
يكى مكان زنى در يك جمعيت است. تعداد آللهاى مؤثر از طريق فرمول ميزان هتروزيخوسى مورد انتظار است (Hedrick, 2005).

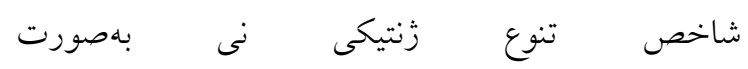
$H_{s}=\frac{1}{k} \cdot \sum_{s=1}^{k} H_{S s}=\frac{1}{k} \cdot \sum_{s=1}^{k}\left[1-q_{s}^{2}-\left(1-q_{s}\right)^{2}\right]$

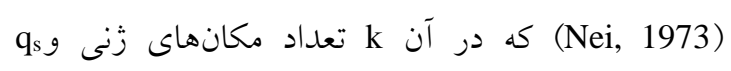
فراوانى آلل مشهود است. شاخص تنوع زنتيكى شانون ب بهورت H= بر آورد شد كه در آن شاخص شانون، pi فراوانى جمعيت iام مىباشد، تعيين

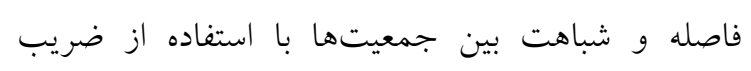

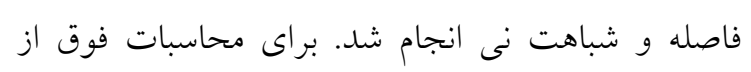

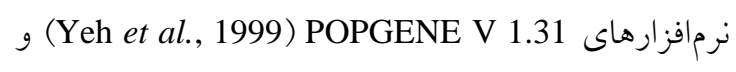

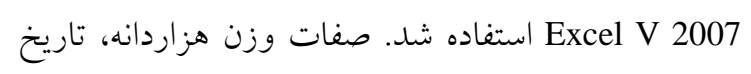
كلدهى، ارتفاع گياه، تعداد ساقه فرعى، تعداد ميانخره در

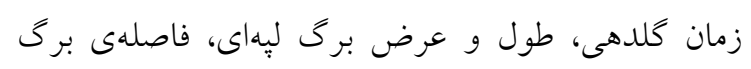

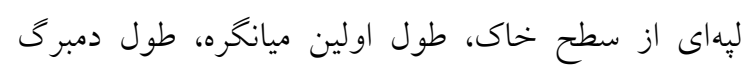

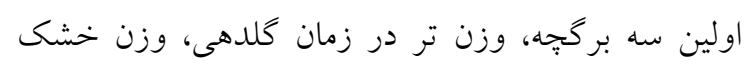

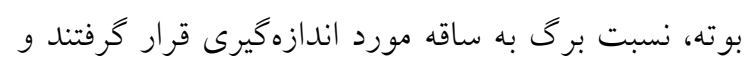

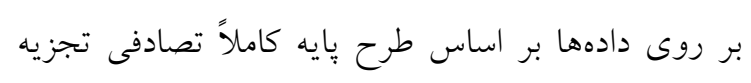

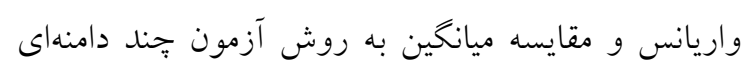

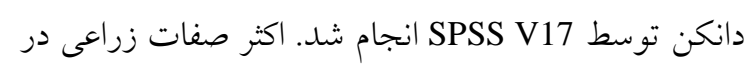
دو جين اندازهيرى شدند و براى صفاتى غير از عملكرد و
ريور) و هفت رقم بومى (همدانى، قره يونجه، يزدى، تازه

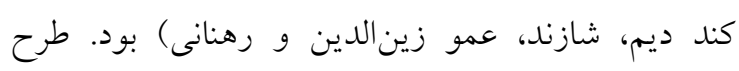

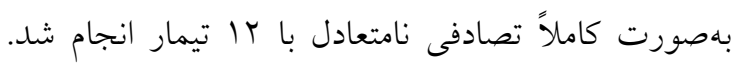
جهت اندازهيرى صفات گياهجهاى يونجه، براى هر جمعيت در نظر كرفته شد. ابعاد كلدانها

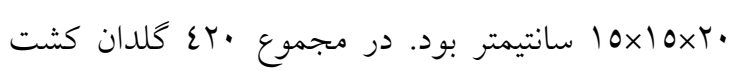

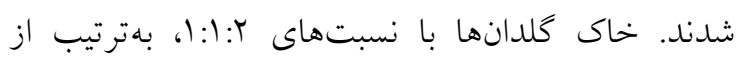

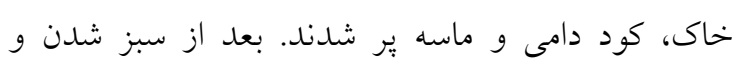

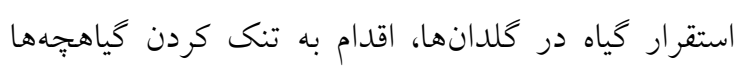

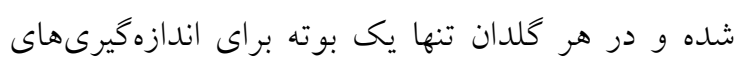

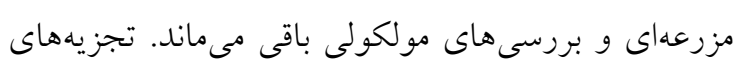

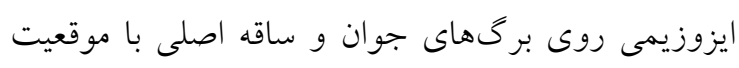

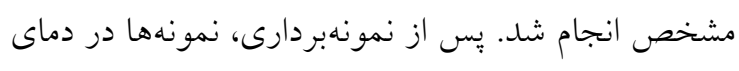

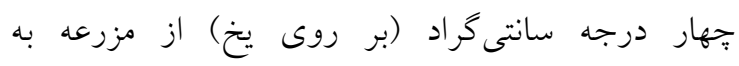

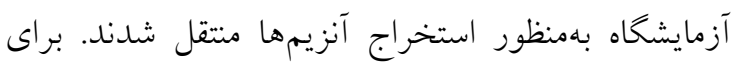

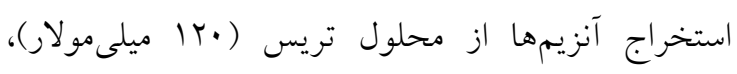

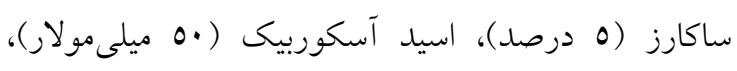

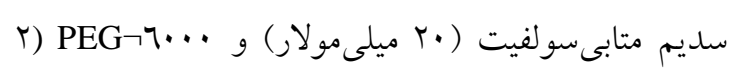

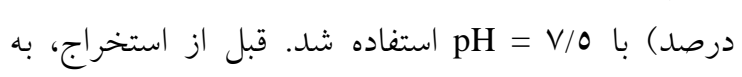
محلول فوق r-مركايتو اتانول به مقدار / / • درصد اضافه -

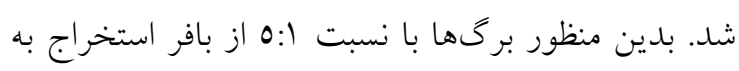

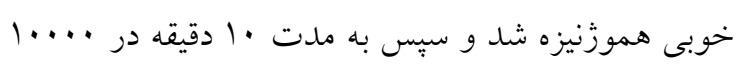

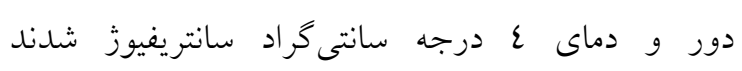

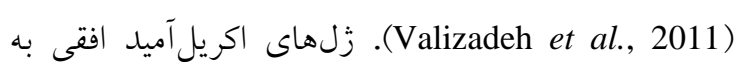
ضخامت 7 ميلىمتر و غلظت V درصد با استفاده از

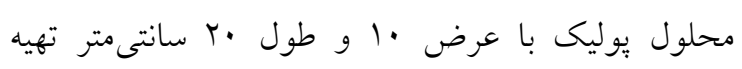

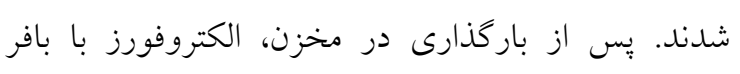

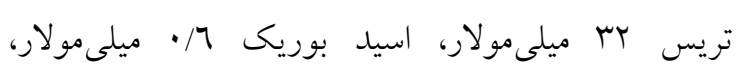

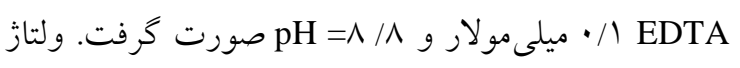
منبع الكتريسيته روى 197 ولت تنظيم شد. بعد از حدود ع-0 ساعت حركت آبى بروموفنول از محل نمونهها به نيه

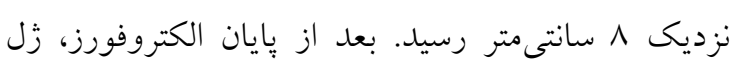

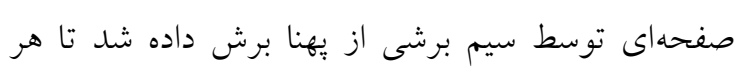

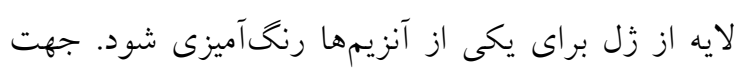


ميانكره و طول اولين دمبرى بيشترى داشت. هرجند كه

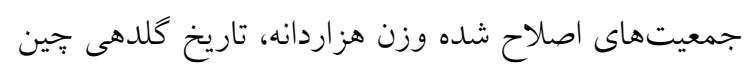

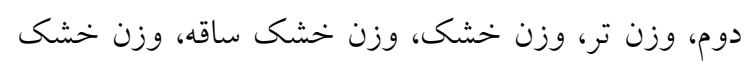

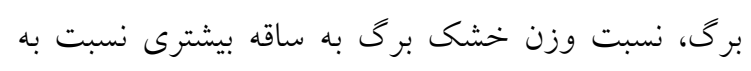

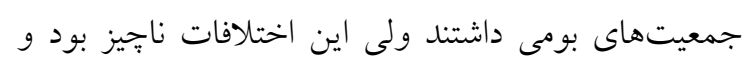

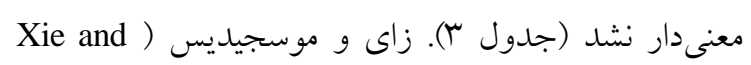
(Mosjidis, 1995 كَاهجهاى و صفات كياه بالغ در شبدر قرمز ضعيف است داست

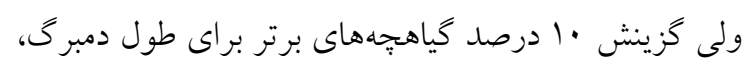

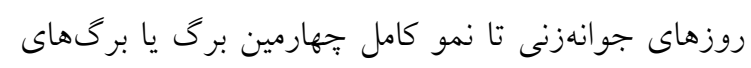
كياهجه مىتواند علوفه خشك انفرادى كياهان و در نهايت

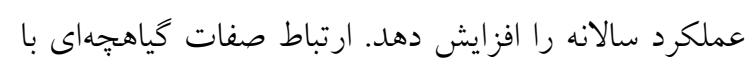

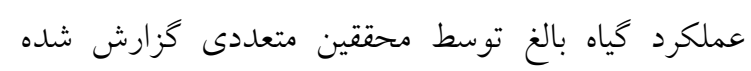
است ) Bouton, 1982; Simons, 1990; Xie and (Mosjidis, 1995

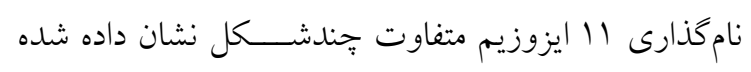

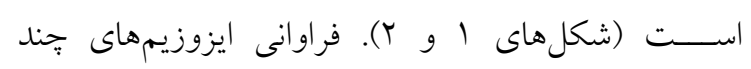

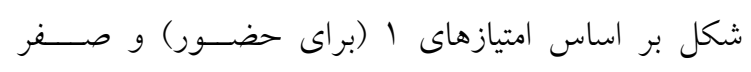

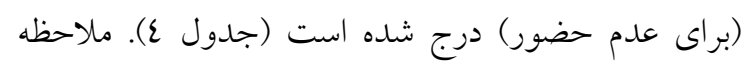

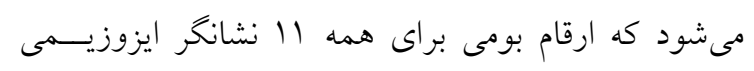

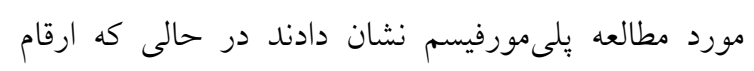

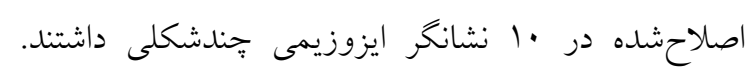

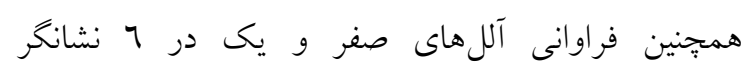

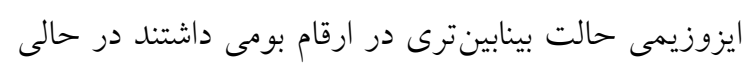

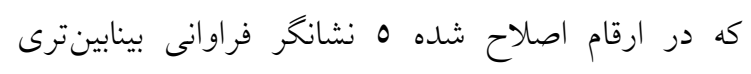

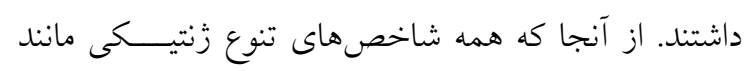

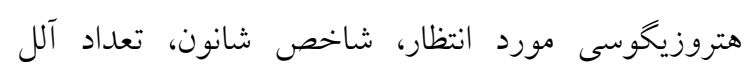

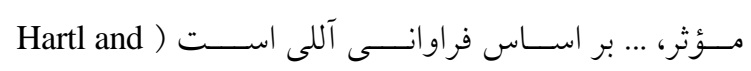

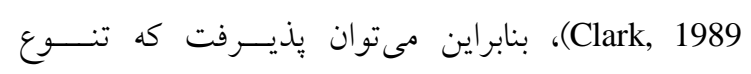

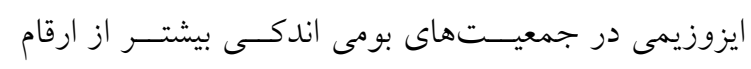

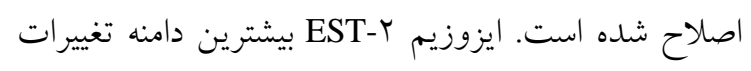

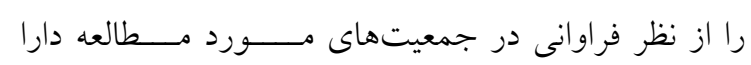

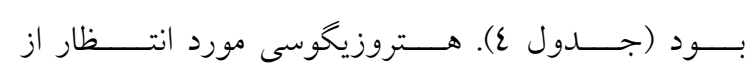

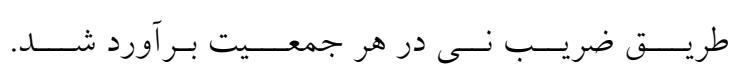

تاريخ كلدهى، ميانگين دو جين، براى صفات عملكرد

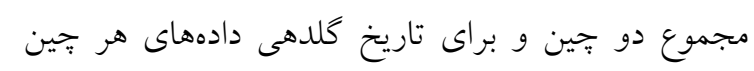
جهت تجزيه واريانس و ساير برآوردها مورد استفاده قرار

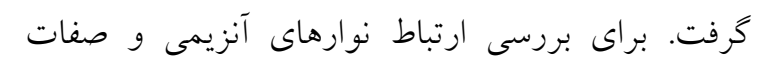

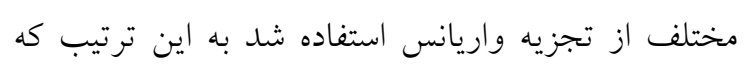

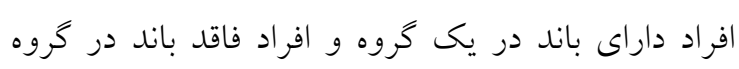

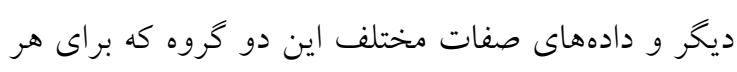

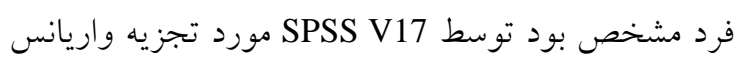
قرار كرفتند.

\section{نتايج و بحث}

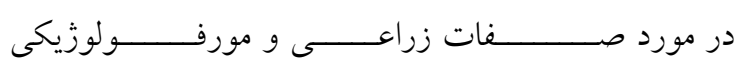

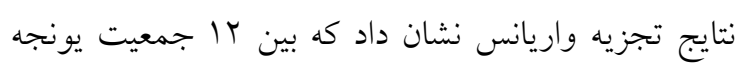

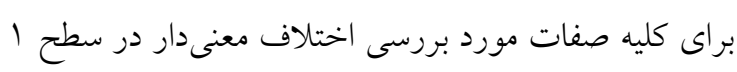

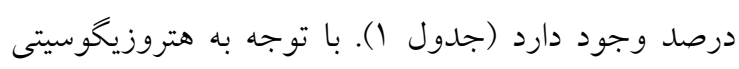
زياد و دكرگشنى قابل توجه در يونجه، تنوع زياد صفات

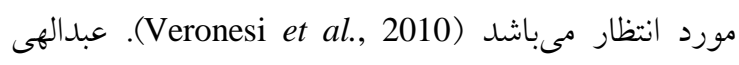
(آزمايشى بهمنظور تعيين تنوع زنتيكى (Abdollahi, 2013)

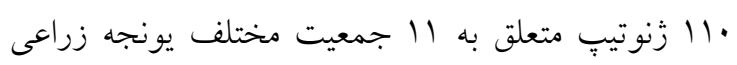

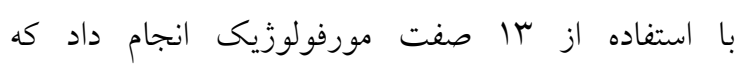
جمعيتها از نظر صفات مورد بررسى اختلاف معنىدارى

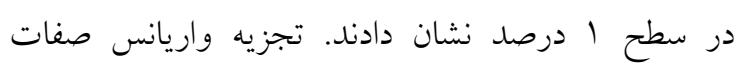

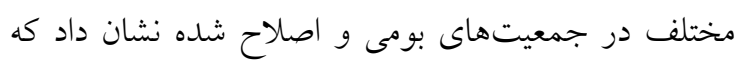
اختلاف معنى دار بين دو جمعيت در رابطه با صفات تعداد

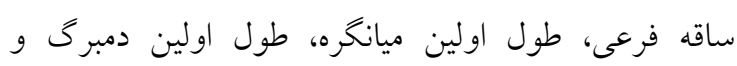

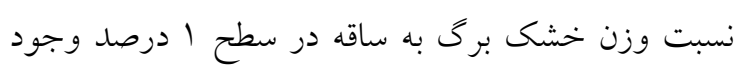

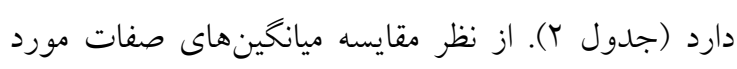

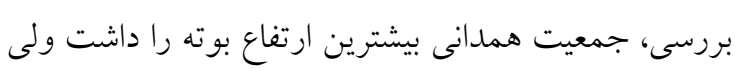

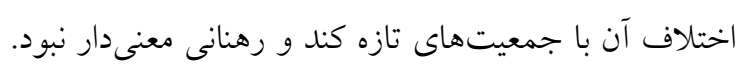

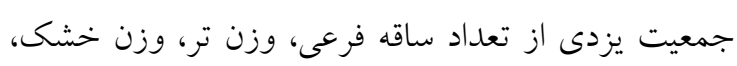

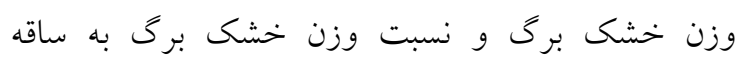
بيشترى برخوردار بود و اختلاف آن با بقيه جمعيتها

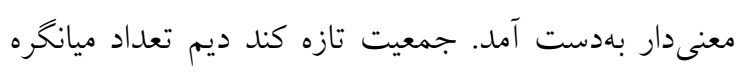

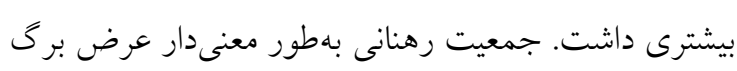

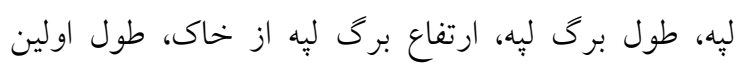


جدول ا- تجزيه واريانس صفات مختلف در rار جمعيت يونجه

Table 1. Analysis of variance in 12 populations of alfalfa for all traits

\begin{tabular}{|c|c|c|c|c|c|c|c|c|c|c|c|c|c|}
\hline \multirow[b]{2}{*}{$\begin{array}{c}\text { منابع تغييرات } \\
\text { Sources of variation }\end{array}$} & \multicolumn{13}{|c|}{$\begin{array}{l}\text { صفات } \\
\text { Traits }\end{array}$} \\
\hline & 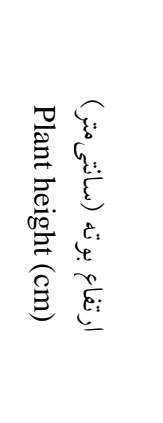 & 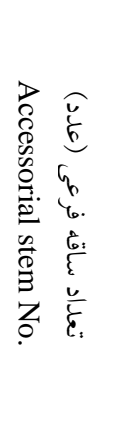 & 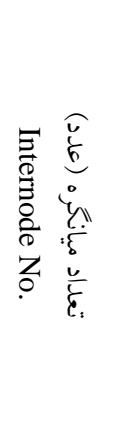 & 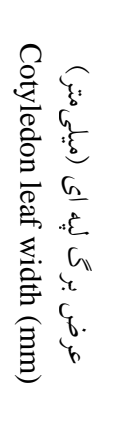 & 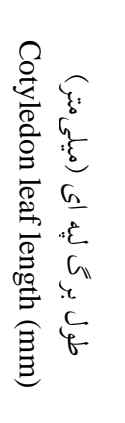 & 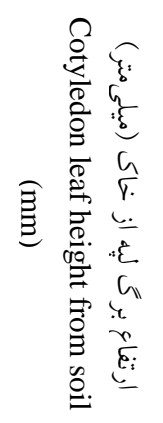 & 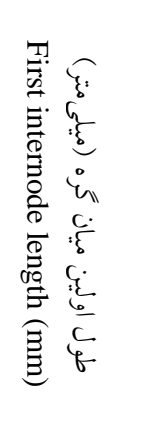 & 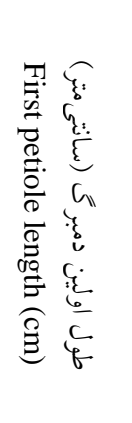 & 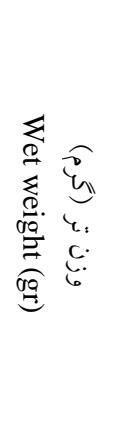 & 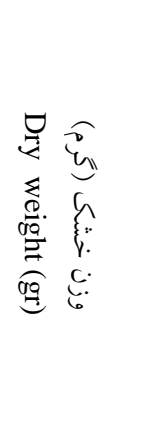 & 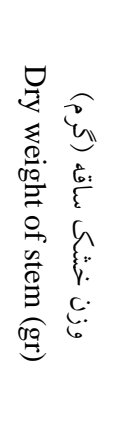 & 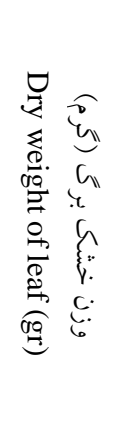 & 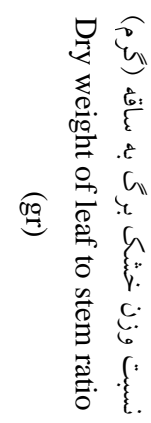 \\
\hline $\begin{array}{c}\text { درجه آزادى تيمار } \\
\text { Degree freedom of treatment }\end{array}$ & 11 & 11 & 11 & 11 & 11 & 11 & 11 & 11 & 11 & 11 & 11 & 11 & 11 \\
\hline $\begin{array}{l}\text { درجه آزادى خطا Degree freedom of error } \\
\text { Dedor }\end{array}$ & 359 & 358 & 358 & 390 & 390 & 390 & 353 & 351 & 355 & 355 & 355 & 355 & 355 \\
\hline $\begin{array}{l}\text { ميانخين مربعات بين جمعيتها (تيمار) } \\
\text { Mean square of treatment }\end{array}$ & $1204.99^{* *}$ & $19.30^{* *}$ & $5.48^{* *}$ & $4.95^{* *}$ & $27.01^{* *}$ & $19.57^{* *}$ & $675.36^{* *}$ & $2.05^{* *}$ & $19.46^{* *}$ & $158.56^{* *}$ & $0.49^{\text {ns }}$ & $50.19^{* *}$ & $0.04^{* *}$ \\
\hline ميانخين مربعات داخل جمعيتها & 122.99 & 4.09 & 2.25 & 0.47 & 2.30 & 7.42 & 236.05 & 0.37 & 3.93 & 42.64 & 0.42 & 13.25 & 0.005 \\
\hline Mean square of error & & & & & & & & & & & & & \\
\hline
\end{tabular}

The squre-root transforamtion for wet weight and No. of auxiliary stems, the inverse transformation for dry weight nad the ArcSin transformation for dry weight of leaf to stem ratio were done for mention data.

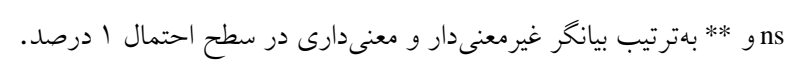

ns and **: non-significant and significant at 0.01 , respectively. 
جدول r- تجزيه واريانس صفات مختلف براى مقايسه جمعيتهاى بومى با جمعيتهاى اصلاح شده يونجه

Table 2. Analysis of variance for all traits to compare landrace and breeding lines populations

Traits

\begin{tabular}{|c|c|c|c|c|c|c|c|c|c|c|c|c|c|}
\hline 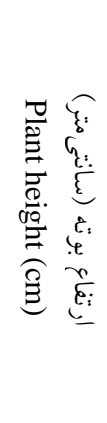 & 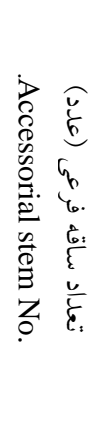 & 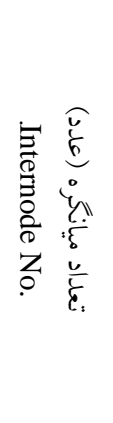 & 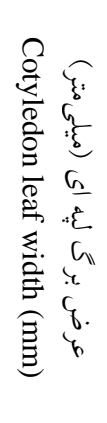 & 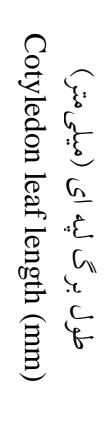 & $\widehat{\Xi}$ & 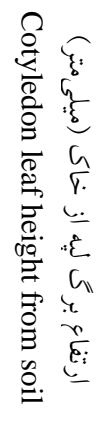 & 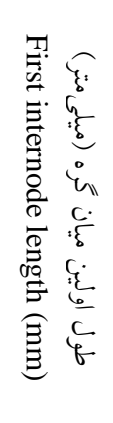 & 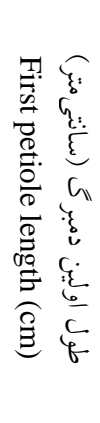 & 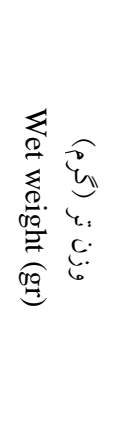 & 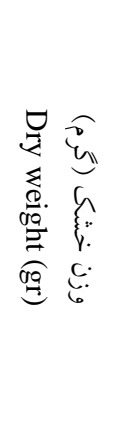 & 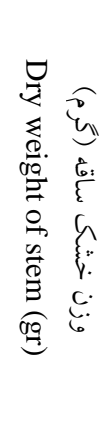 & 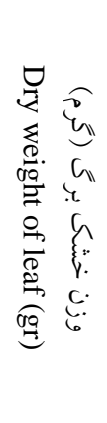 & 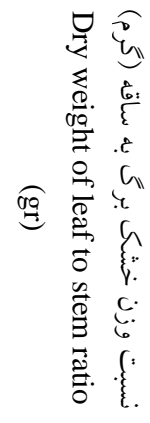 \\
\hline
\end{tabular}

$\begin{array}{lllllllllllll}1 & 1 & 1 & 1 & 1 & 1 & 1 & 1 & 1 & 1\end{array}$

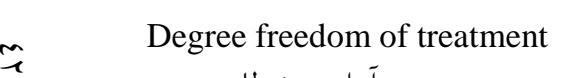

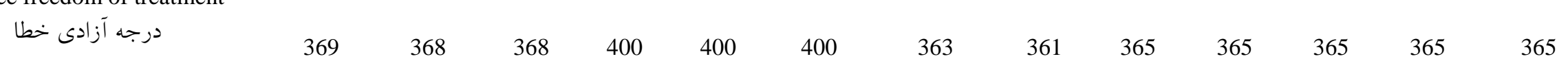

Degree freedom of error

\begin{tabular}{|c|c|c|c|c|c|c|c|c|c|c|c|c|c|}
\hline $\begin{array}{l}\text { Degree freedom of error } \\
\text { ميانخين مربعات بين جمعيتها (تيمار) } \\
\text { Mean square of treatment }\end{array}$ & $149.7^{\mathrm{ns}}$ & $56.51^{* *}$ & $0.54^{\mathrm{ns}}$ & $1.91^{\mathrm{ns}}$ & $5.31^{\mathrm{ns}}$ & $1.21^{\mathrm{ns}}$ & $4454.91^{* *}$ & $2.68^{* *}$ & $5.54^{\mathrm{ns}}$ & $73.94^{\mathrm{ns}}$ & $1.45^{\mathrm{ns}}$ & $47.31^{\mathrm{ns}}$ & $0.04^{* *}$ \\
\hline $\begin{array}{c}\text { ميانخين مربعات داخل جمعيتها (خطا) } \\
\text { Mean square of error }\end{array}$ & 155.18 & 4.40 & 2.35 & 0.59 & 2.97 & 7.73 & 237.74 & 0.41 & 4.44 & 46.05 & 0.42 & 14.27 & 0.006 \\
\hline
\end{tabular}

براى تعداد ساقه فرعى و وزن تر تبديل داده از نوع جذرى، براى وزن خشك ساقه از نوع معكوس و براى نسبت وزن خشك برى به ساقه از نوع Arctan انجام شد.

The squre-root transforamtion for wet wight and No. of auxiliary stems, the inverse transformation for dry wight nad ArcSin transformation were done for mention data.

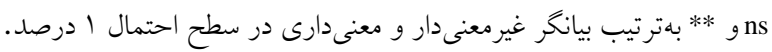

ns and **: non-significant and highly significant at 0.01 , respectively. 
جدول r- ميانخين صفات بررسى شده در جمعيتهاى يونجه مورد مطالعه .

Table 3. Mean of traits in all populations of alfalfa

\begin{tabular}{|c|c|c|c|c|c|c|c|c|c|c|c|c|c|c|c|c|}
\hline جمعيت Population & 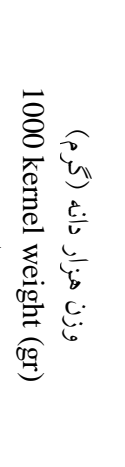 & 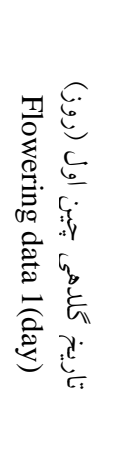 & 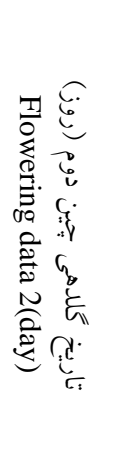 & 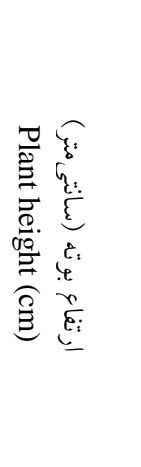 & 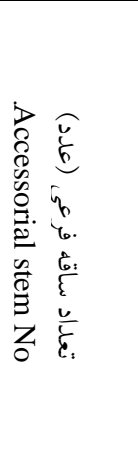 & 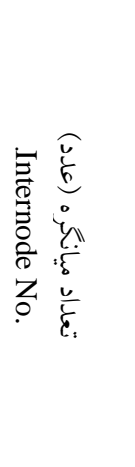 & 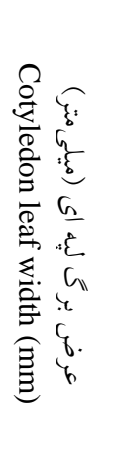 & 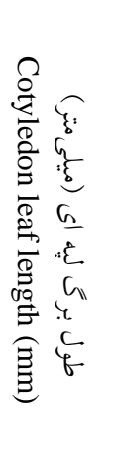 & 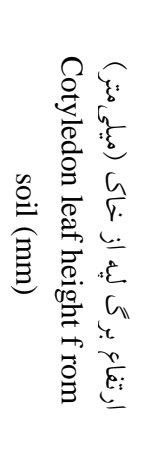 & 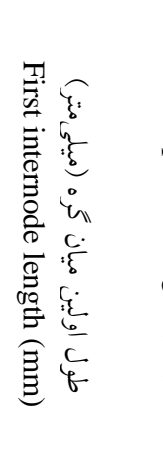 & 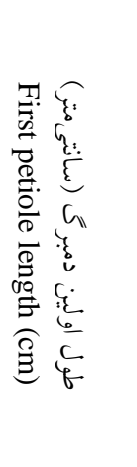 & 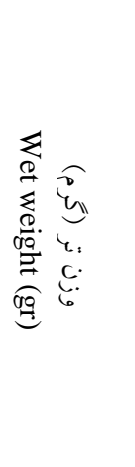 & 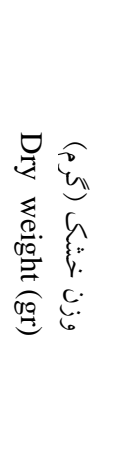 & 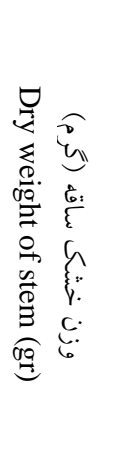 & 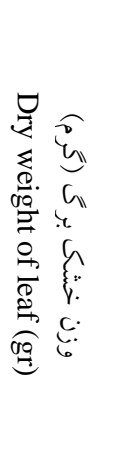 & 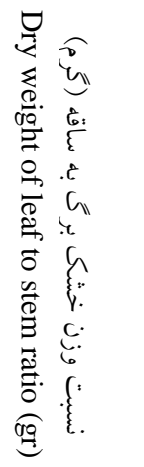 \\
\hline Gharayonje & $1.59 \mathrm{j}$ & $31 b$ & $29 b$ & $29.49 d$ & $4.76 \mathrm{de}$ & $6.03 b c$ & $3.51 b c$ & $7.41 \mathrm{bcd}$ & $6.06 \mathrm{bc}$ & $48.65 \mathrm{ab}$ & $1.66 \mathrm{ab}$ & $4.25 c$ & $5.21 \mathrm{c}$ & $0.27 \mathrm{a}$ & $3.32 \mathrm{~d}$ & $1.29 \mathrm{a}$ \\
\hline Amozeynedin & 1.361 & $32 \mathrm{a}$ & $29 b$ & $41.09 \mathrm{bc}$ & $4.75 \mathrm{de}$ & $6.53 b c$ & $3.19 \mathrm{~cd}$ & $6.93 d$ & $5.64 b c$ & $47.31 \mathrm{abc}$ & $1.48 b c$ & $5.96 \mathrm{~b}$ & $9.95 \mathrm{~b}$ & $0.06 \mathrm{ab}$ & $5.57 \mathrm{c}$ & $1.22 \mathrm{cde}$ \\
\hline رهنانى Rahnani & $2.80 \mathrm{a}$ & $31 b$ & $29 b$ & $50.36 a$ & $6.57 \mathrm{ab}$ & $7.17 \mathrm{ab}$ & $4.54 \mathrm{a}$ & $10.31 \mathrm{a}$ & $8.21 \mathrm{a}$ & $49.76 \mathrm{a}$ & $1.94 \mathrm{a}$ & $6.89 \mathrm{ab}$ & $12.94 \mathrm{ab}$ & $0.14 a b$ & $7.11 \mathrm{abc}$ & $1.19 \mathrm{de}$ \\
\hline Tazekand & $1.45 \mathrm{k}$ & $31 b$ & $29 b$ & $50.75 a$ & $6.06 \mathrm{bc}$ & $7.61 \mathrm{a}$ & $3.38 \mathrm{bcd}$ & $7.33 \mathrm{bcd}$ & $6.52 b c$ & $40.65 \mathrm{abcd}$ & $1.92 \mathrm{a}$ & 7.04ab & $12.50 \mathrm{ab}$ & $0.02 \mathrm{ab}$ & 6.94abc & $1.19 \mathrm{e}$ \\
\hline شازند Shazand & $1.67 \mathrm{i}$ & $31 b$ & $29 b$ & $46.77 \mathrm{ab}$ & $5.67 \mathrm{bcd}$ & $7.03 \mathrm{ab}$ & $3.3 \mathrm{bcd}$ & $7.19 \mathrm{~cd}$ & $6.43 b c$ & 42.66abcd & $1.34 \mathrm{bcd}$ & $6.63 b$ & $11.06 \mathrm{~b}$ & $0.18 \mathrm{ab}$ & $6.30 \mathrm{bc}$ & $1.22 \mathrm{bcde}$ \\
\hline همدانى Hamedani & $2.05 \mathrm{e}$ & $32 \mathrm{a}$ & $30 \mathrm{a}$ & $51.28 \mathrm{a}$ & $5.29 \mathrm{cde}$ & 7.09ab & $3.47 \mathrm{bc}$ & $7.81 \mathrm{bc}$ & $6.90 \mathrm{abc}$ & $46.43 \mathrm{abc}$ & $1.11 \mathrm{~d}$ & $6.21 \mathrm{ab}$ & $10.15 \mathrm{ab}$ & $0.05 \mathrm{~b}$ & $5.85 \mathrm{bc}$ & $1.22 \mathrm{bcde}$ \\
\hline يزدى Yazdi & $1.87 \mathrm{~h}$ & $31 \mathrm{~b}$ & $29 \mathrm{~b}$ & $43.69 \mathrm{bc}$ & $7.18 \mathrm{a}$ & $6.94 \mathrm{ab}$ & $3.36 \mathrm{bcd}$ & $8.06 \mathrm{~b}$ & $6.36 \mathrm{bc}$ & 43.24abcd & $1.52 b c$ & $6.53 \mathrm{a}$ & $13.32 \mathrm{a}$ & $0.09 \mathrm{ab}$ & $7.94 \mathrm{a}$ & $1.24 \mathrm{a}$ \\
\hline كايسارى Kaysari & $1.92 \mathrm{~g}$ & $31 b$ & $29 b$ & $47.06 \mathrm{ab}$ & $4.32 \mathrm{e}$ & $6.59 b c$ & $3.53 b c$ & $8.06 \mathrm{~b}$ & 7.16ab & 41.93abcd & $1.57 \mathrm{bc}$ & $6.49 \mathrm{ab}$ & $11.25 \mathrm{ab}$ & $0.05 b$ & $6.62 b c$ & $1.25 \mathrm{cde}$ \\
\hline Renger رنجر & $2.08 \mathrm{~d}$ & $31 b$ & $29 b$ & $43.55 b c$ & $5.56 \mathrm{bcd}$ & $7.07 \mathrm{ab}$ & $3.28 \mathrm{bcd}$ & $7.36 \mathrm{bcd}$ & $6.56 b c$ & $36.36 \mathrm{~d}$ & $1.28 \mathrm{~cd}$ & $6.55 \mathrm{ab}$ & $10.29 \mathrm{ab}$ & $0.13 \mathrm{ab}$ & $6.05 \mathrm{ab}$ & $1.22 \mathrm{bcd}$ \\
\hline كدى Kadi & $1.95 \mathrm{f}$ & $31 b$ & $29 b$ & $43.81 b c$ & $4.97 \mathrm{cde}$ & $6.6 b c$ & $3.01 \mathrm{~d}$ & $7.17 \mathrm{~cd}$ & $5.47 \mathrm{c}$ & $35.65 d$ & $1.27 \mathrm{~cd}$ & $6.76 \mathrm{ab}$ & 11.36ab & $0.00 \mathrm{ab}$ & $6.92 \mathrm{abc}$ & $1.29 \mathrm{abc}$ \\
\hline مسمير Mesmir & $2.21 \mathrm{c}$ & $31 b$ & $30 \mathrm{a}$ & $43.42 b c$ & $4.87 \mathrm{de}$ & $6.74 \mathrm{abc}$ & $3.57 \mathrm{~b}$ & $7.82 b c$ & $6.07 \mathrm{bc}$ & $40.03 \mathrm{bcd}$ & $1.30 \mathrm{bcd}$ & $7.41 \mathrm{ab}$ & $14.13 \mathrm{ab}$ & $0.02 \mathrm{ab}$ & $8.68 \mathrm{abc}$ & $1.28 \mathrm{a}$ \\
\hline سى ريور Sea river & $2.36 \mathrm{~b}$ & $32 \mathrm{a}$ & $30 \mathrm{a}$ & $39.65 \mathrm{c}$ & $4.71 \mathrm{de}$ & 7.19ab & $3.63 \mathrm{~b}$ & $7.72 \mathrm{bcd}$ & $7.19 \mathrm{ab}$ & $38.62 \mathrm{~cd}$ & $1.47 \mathrm{bc}$ & $6.09 \mathrm{~b}$ & $10.29 \mathrm{ab}$ & $0.06 \mathrm{ab}$ & $6.20 \mathrm{bc}$ & $1.27 \mathrm{ab}$ \\
\hline بومى Landraces & 1.83 & 31.29 & 29.14 & 44.78 & $5.75 a$ & 6.91 & 3.54 & 7.86 & 6.59 & $45.53 \mathrm{a}$ & $1.57 \mathrm{a}$ & 6.25 & 10.48 & 0.05 & 6.04 & $1.23 \mathrm{~b}$ \\
\hline اصلاح شده Improved & 2.10 & 31.20 & 29.40 & 43.50 & $4.89 b$ & 6.84 & 3.40 & 7.63 & 6.49 & $38.52 b$ & $1.38 \mathrm{~b}$ & 6.50 & 11.39 & 0.08 & 6.76 & $1.25 \mathrm{a}$ \\
\hline
\end{tabular}




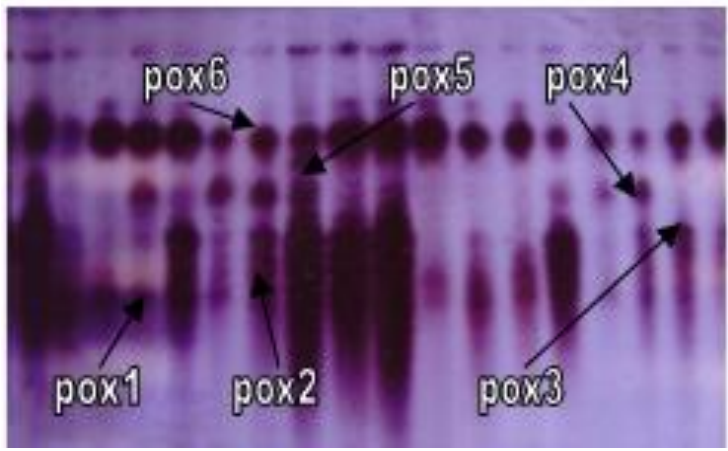

شكل r- نام گذارى ايزوزيمهاى تجندشكل بر اكسيداز

Figure 2. Naming of polymorphic proxidase isozymes

نشانكر RAPD براى مطالعهى تنوع زنتيكى و صفات

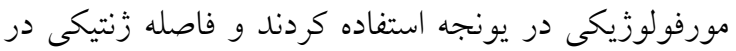

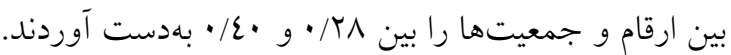
از نظر ارتباط نوارهاى ايزوزيمى و صفات مورد بررسى در جمعيتهاى بومى، ايزوزيم EST-I با صفت طول اولين دمبرى در ارتباط است و وجود اين نوار باعث كاهش طول اولين دمبرك شده است. ايزوزيم برگ لٍه از خاك و نسبت وزن خشك برى به ساقه ارتباط

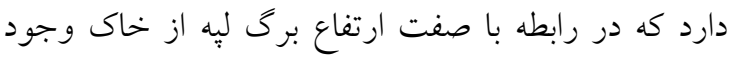
اين نوار باعث كاهش اين صفت و در رابطه با صفت نسبت وزن خشك برگ به ساقه وجود اين نوار باعث افزايش اين صفت شده است. ايزوزيم ب-POX با صفت عرض برى لِهاى ارتباط دارد و وجود اين نوار باعث كاهش اين صفت شده است. ايزوزيم POX-0 با صفت تعداد ميانكره ارتباط دارد و وجود اين نوار باعث افزايش اين صفت شده است. ساير نوارها ارتباط معنىدارى با صفات نشان ندادند. در مورد جمعيتهاى اصلاح شده ايزوزيم EST- با صفت تعداد ساقه فرعى ارتباط دارد و وجود اين نوار باعث افزايش اين صفت شده است. ايزوزيم POX-Y با صفت وزن خشى برى ارتباط معنىدارى دارد و وجود اين نوار باعث افزايش اين صفت شده است. ايزوزيم r-POX با صفت تعداد ساقه فرعى ارتباط معنىدار داشت و وجود اين نوار باعث كاهش اين صفت شده

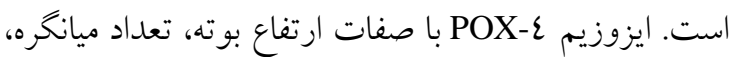
وزن تر بوته، وزن خشك بوته، وزن خشك ساقه و وزن إن إن خشى برى ارتباط نشان داد و در همه مــــــــارد وجــــــود نوار باعـــث افزايــــش اين صـــــــات شد.

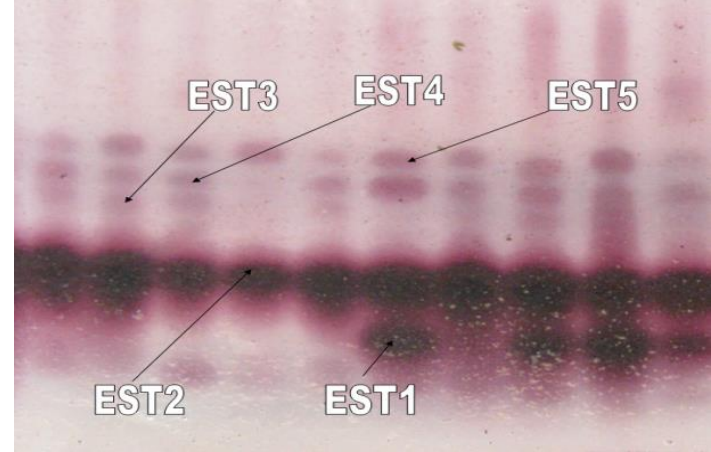

شكل ا- نام گذارى ايزوزيمهاى جنـد شكل استراز Figure 1. Naming of polymorphic esterase isozymes

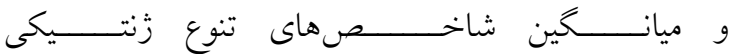
بهدست آمد و نتايج نشان داد كه رقم كدى شاخصهاى

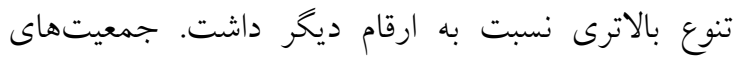
اصلاح شده با دارا بودن مقدار 1019• براى شاخص شانون برن و مقدار rOr/ ب براى تنوع زنتيكى نى، تفاوت جشمخيرى نسبت به جمعيتهاى بومى نشان ندادند. مىتوان نتيجه كرفت اين دو نوع جمعيت تفاوت قابل توجهى با يكديكر نداشتند (جدول 0). وليزاده و همكاران ( Valizadeh et al., 2011) براى بررسى تنوع درون و بين ارقام يونجه از

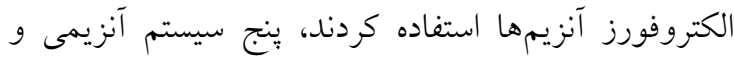

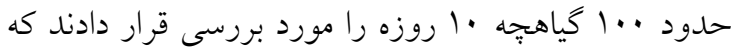
سه مكان زنى ايزوزيم تشخيص داده شد و سطح بالايى از

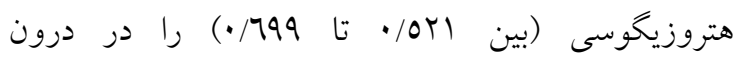
جمعيتهاى يونجه بهدست آوردند. منكونى و همكاران سطح بالايى از تنوع را درون و (Mengoni et al., 2000)

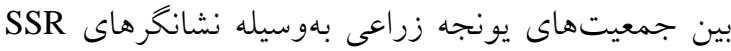

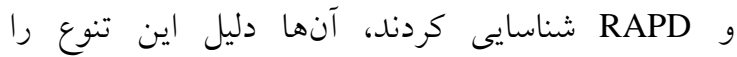
دكرگردهافشانى و ساختار تترايلوئيدى يونجه ذكر كردند. فاصله زننيكى بين جمعيتها از طريق فرمول نى محاسبه شد كه كمترين فاصله متعلق به ارقام تازه كند ديم و قره يونجه است و بيشترين فاصله متعلق به ارقام يزدى و كدى است. در كل مىتوان فاصله زنتيكى بسيار باييين بين ارقام و

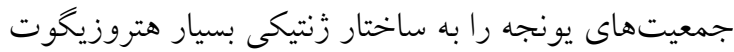
و وراثت تتراسوميك يونجه نسبت داد. فاصله زنتيكى ارقام اصلاح شده و بومى نيز ا درصد بود، بنابراين ارقام بومى و اصلاح شده حدود 99 درصد به يكديخر شباهت دارند

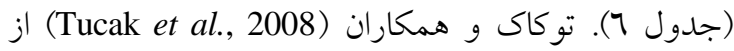


جدول ع- فراوانى ايزوزيمها در جمعيتهاى يونجه

Table 4. Frequency of isozymes in alfalfa populations

\begin{tabular}{|c|c|c|c|c|c|c|c|c|c|c|c|c|c|c|c|c|}
\hline ميانخين & $\begin{array}{l}\text { اصلاح شده } \\
\text { Improved }\end{array}$ & $\begin{array}{c}\text { بومى } \\
\text { Landraces }\end{array}$ & $\begin{array}{l}\text { سى ريور } \\
\text { Sea river }\end{array}$ & $\begin{array}{c}\text { Mesmir } \\
\text { Mسمير } \\
\end{array}$ & $\begin{array}{l}\text { كدى } \\
\text { Kadi }\end{array}$ & $\begin{array}{c}\text { رنجر } \\
\text { Renger }\end{array}$ & $\begin{array}{l}\text { كايسارى } \\
\text { Kaysari }\end{array}$ & $\begin{array}{l}\text { يزدى } \\
\text { Yazdi }\end{array}$ & $\begin{array}{c}\text { همدانى } \\
\text { Hamedani }\end{array}$ & $\begin{array}{c}\text { شازند } \\
\text { Shazand }\end{array}$ & $\begin{array}{c}\text { تازه كند } \\
\text { Tazekand }\end{array}$ & $\begin{array}{c}\text { رهنانى } \\
\text { Rahnani }\end{array}$ & $\begin{array}{c}\text { عمو زين الدين } \\
\text { Amozeynedin }\end{array}$ & $\begin{array}{c}\text { قره يونجه } \\
\text { Gharayonje }\end{array}$ & & $\begin{array}{l}\text { ايزوزيمها } \\
\text { Isozymes } \\
\end{array}$ \\
\hline 0.81 & 0.78 & 0.83 & 0.90 & 0.83 & 0.74 & 0.75 & 0.79 & 0.86 & 0.71 & 0.77 & 0.88 & 0.78 & 0.84 & 0.85 & 0 & \multirow{2}{*}{ EST1 } \\
\hline 0.19 & 0.22 & 0.17 & 0.10 & 0.17 & 0.26 & 0.25 & 0.21 & 0.14 & 0.29 & 0.23 & 0.12 & 0.22 & 0.16 & 0.15 & 1 & \\
\hline 0.02 & 0.00 & 0.01 & 0.05 & 0.00 & 0.14 & 0.00 & 0.00 & 0.00 & 0.00 & 0.00 & 0.00 & 0.00 & 0.06 & 0.00 & 0 & \multirow{2}{*}{ EST2 } \\
\hline 0.98 & 1.00 & 0.99 & 0.95 & 1.00 & 0.86 & 1.00 & 1.00 & 1.00 & 1.00 & 1.00 & 1.00 & 1.00 & 0.94 & 1.00 & 1 & \\
\hline 0.64 & 0.53 & 0.66 & 0.85 & 0.90 & 0.52 & 0.41 & 0.66 & 0.71 & 0.32 & 0.42 & 0.67 & 0.71 & 0.73 & 0.74 & 0 & \multirow{2}{*}{ EST3 } \\
\hline 0.36 & 0.47 & 0.34 & 0.15 & 0.10 & 0.48 & 0.59 & 0.34 & 0.29 & 0.68 & 0.58 & 0.33 & 0.29 & 0.27 & 0.26 & 1 & \\
\hline 0.44 & 0.56 & 0.48 & 0.58 & 0.30 & 0.37 & 0.24 & 0.35 & 0.38 & 0.67 & 0.54 & 0.47 & 0.47 & 0.34 & 0.52 & 0 & \multirow{2}{*}{ EST4 } \\
\hline 0.56 & 0.44 & 0.52 & 0.42 & 0.70 & 0.63 & 0.76 & 0.65 & 0.62 & 0.33 & 0.46 & 0.53 & 0.53 & 0.66 & 0.48 & 1 & \\
\hline 0.68 & 0.63 & 0.70 & 0.58 & 0.64 & 0.74 & 0.75 & 0.83 & 0.46 & 0.74 & 0.84 & 0.71 & 0.67 & 0.64 & 0.60 & 0 & \multirow{2}{*}{ EST5 } \\
\hline 0.32 & 0.37 & 0.30 & 0.42 & 0.36 & 0.26 & 0.25 & 0.17 & 0.54 & 0.26 & 0.16 & 0.29 & 0.33 & 0.36 & 0.40 & 1 & \\
\hline 0.47 & 0.36 & 0.47 & 0.58 & 0.42 & 0.60 & 0.37 & 0.67 & 0.38 & 0.36 & 0.62 & 0.35 & 0.52 & 0.52 & 0.20 & 0 & \multirow{2}{*}{ PRX1 } \\
\hline 0.53 & 0.64 & 0.53 & 0.42 & 0.58 & 0.40 & 0.63 & 0.33 & 0.62 & 0.64 & 0.38 & 0.65 & 0.48 & 0.48 & 0.80 & 1 & \\
\hline 0.58 & 0.60 & 0.58 & 0.65 & 0.63 & 0.56 & 0.56 & 0.48 & 0.53 & 0.63 & 0.44 & 0.65 & 0.48 & 0.60 & 0.71 & 0 & \multirow{2}{*}{ PRX2 } \\
\hline 0.42 & 0.40 & 0.42 & 0.35 & 0.37 & 0.44 & 0.44 & 0.52 & 0.47 & 0.37 & 0.56 & 0.35 & 0.52 & 0.40 & 0.29 & 1 & \\
\hline 0.80 & 0.73 & 0.83 & 0.79 & 0.72 & 0.90 & 0.85 & 0.77 & 0.76 & 0.72 & 0.88 & 0.84 & 0.88 & 0.74 & 0.76 & 0 & \multirow{2}{*}{ PRX3 } \\
\hline 0.20 & 0.27 & 0.17 & 0.21 & 0.28 & 0.10 & 0.15 & 0.23 & 0.24 & 0.28 & 0.12 & 0.16 & 0.12 & 0.26 & 0.24 & 1 & \\
\hline 0.59 & 0.60 & 0.57 & 0.58 & 0.59 & 0.85 & 0.52 & 0.64 & 0.38 & 0.69 & 0.62 & 0.61 & 0.56 & 0.48 & 0.58 & 0 & \multirow{2}{*}{ PRX4 } \\
\hline 0.41 & 0.40 & 0.43 & 0.42 & 0.41 & 0.15 & 0.48 & 0.36 & 0.62 & 0.31 & 0.38 & 0.39 & 0.44 & 0.52 & 0.42 & 1 & \\
\hline 0.88 & 0.92 & 0.91 & 0.87 & 0.86 & 0.80 & 0.83 & 0.88 & 0.93 & 0.91 & 0.98 & 0.87 & 0.85 & 0.95 & 0.89 & 0 & \multirow{2}{*}{ PRX5 } \\
\hline 0.12 & 0.08 & 0.09 & 0.13 & 0.14 & 0.20 & 0.17 & 0.12 & 0.07 & 0.09 & 0.02 & 0.13 & 0.15 & 0.05 & 0.11 & 1 & \\
\hline 0.03 & 0.06 & 0.01 & 0.21 & 0.00 & 0.05 & 0.05 & 0.00 & 0.00 & 0.00 & 0.00 & 0.00 & 0.00 & 0.09 & 0.00 & 0 & \multirow{2}{*}{ PRX6 } \\
\hline 0.97 & 0.94 & 0.99 & 0.79 & 1.00 & 0.95 & 0.95 & 1.00 & 1.00 & 1.00 & 1.00 & 1.00 & 1.00 & 0.91 & 1.00 & 1 & \\
\hline
\end{tabular}


جدول 0- ميانكين شاخصهاى تنوع زنتيكى كليهى جمعيتهاى يونجه از لحاظ تمام ايزوزيمها

Table 5. Means of genetic diversity indices for all isozymes in all populations of alfalfa

\begin{tabular}{|c|c|c|c|c|c|c|}
\hline زرميلاسم & جمعيت & Population & $\begin{array}{c}\text { تعداد نمونه } \\
\text { No. of samples }\end{array}$ & $\begin{array}{c}\text { تعداد آللهاى مؤثر } \\
\text { No. of effective allels }\end{array}$ & $\begin{array}{c}\text { تنوع زنتيكى نى } \\
\text { Nei's genetic diversity }\end{array}$ & $\begin{array}{c}\text { شاخص شانون } \\
\text { Shanon index }\end{array}$ \\
\hline \multirow{7}{*}{$\begin{array}{c}\text { بومى } \\
\text { landraces }\end{array}$} & قره يونجه & Gharayonje & 23 & $1.5299 \pm 0.3569$ & $0.3090 \pm 0.1800$ & $0.4584 \pm 0.2508$ \\
\hline & عمو زينالدين & Amozeynedin & 20 & $1.6744 \pm 0.2804$ & $0.3846 \pm 0.1220$ & $0.5647 \pm 0.1477$ \\
\hline & رهنانى & Rahnani & 20 & $1.5985 \pm 0.3950$ & $0.3320 \pm 0.1923$ & $0.4830 \pm 0.2638$ \\
\hline & تازه كند ديم & Tazekand & 21 & $1.5472 \pm 0.3693$ & $0.3139 \pm 0.1858$ & $0.4631 \pm 0.2566$ \\
\hline & شازند & Shazand & 22 & $1.5369 \pm 0.4161$ & $0.2991 \pm 0.2070$ & $0.4386 \pm 0.2828$ \\
\hline & همدانى & Hamedani & 22 & $1.5665 \pm 0.3338$ & $0.3268 \pm 0.1812$ & $0.4784 \pm 0.2557$ \\
\hline & يزدى & Yazdi & 14 & $1.5836 \pm 0.3937$ & $0.3247 \pm 0.1963$ & $0.4733 \pm 0.2687$ \\
\hline \multirow{7}{*}{$\begin{array}{l}\text { اصلاح شده } \\
\text { Improved }\end{array}$} & كايسارى & Kaysari & 19 & $1.5455 \pm 0.3478$ & $0.3170 \pm 0.1790$ & $0.4679 \pm 0.2508$ \\
\hline & رنجر & Renger & 20 & $1.6183 \pm 0.3088$ & $0.3576 \pm 0.1453$ & $0.5265 \pm 0.1973$ \\
\hline & كدى & Kadi & 22 & $1.6736 \pm 0.2704$ & $0.3869 \pm 0.1075$ & $0.5700 \pm 0.1223$ \\
\hline & مسمير & Mesmir & 23 & $1.5408 \pm 0.3677$ & $0.3112 \pm 0.1861$ & $0.4597 \pm 0.2570$ \\
\hline & سى ريور & Sea river & 23 & $1.6847 \pm 0.3064$ & $0.3866 \pm 0.1206$ & $0.5684 \pm 0.1361$ \\
\hline & بومى & Landraces & 20 & $1.577 \pm 0.364$ & $0.327 \pm 0.181$ & $0.48 \pm 0.247$ \\
\hline & اصلاح شده & Improved & 21 & $1.612 \pm 0.872$ & $0.352 \pm 0.148$ & $0.519 \pm 0.193$ \\
\hline
\end{tabular}

جدول 7- فاصله زنتيكى نى از طريق دادههاى ايزوزيمى در جمعيتهاى يونجه

Table 6. Nei's genetic distance based on isozyme data in all populations of alfalfa

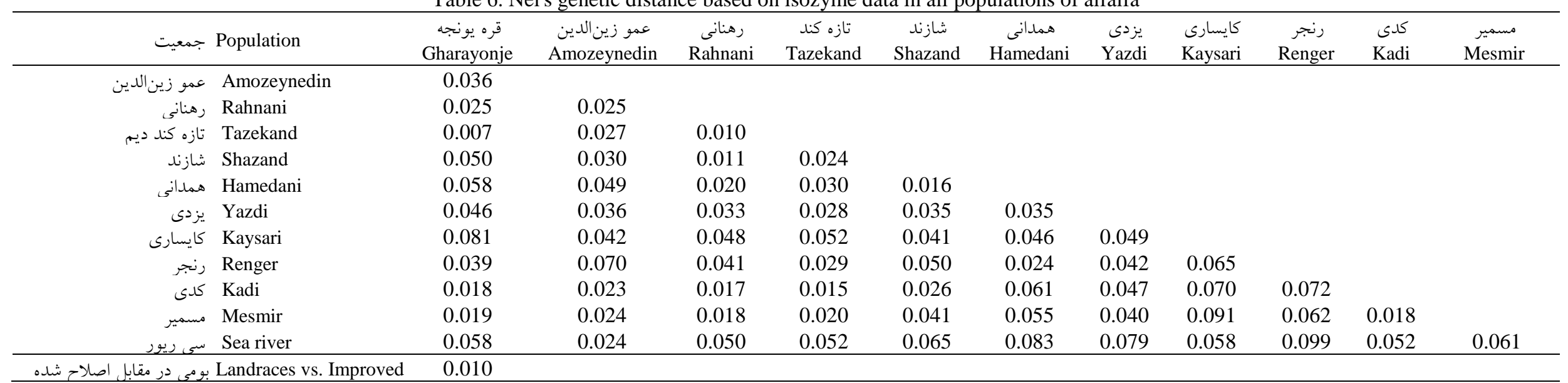


جدول V- ارتباط معنى دار بين ميانخين صفات بررسى شده و نوارهاى آنزيمى در جمعيتهاى بومى و اصلاح شده

Table 7. Significant relation between mean of traits and enzymes bands in landraces and improved populations

Traits / صفات

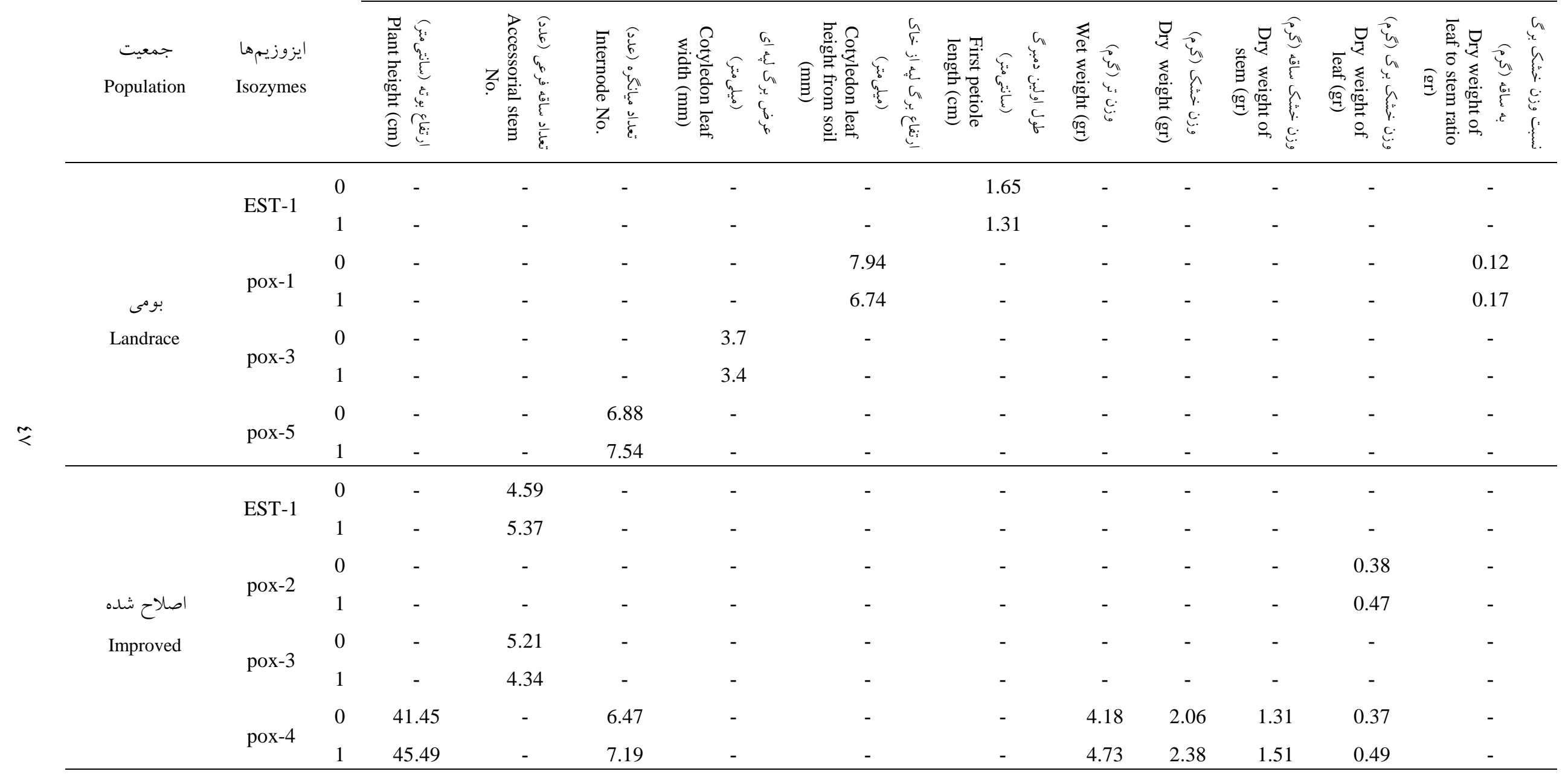

-: No significant different.

- - عدم وجود اختلاف معنى دار.

No significant different in cotyledon leaf length and first internode length traits for all strips.

براى صفات طول برك لِّاى و طول اولين ميانكره عدم وجود اختلاف معنى دار در كليه نوارها. 


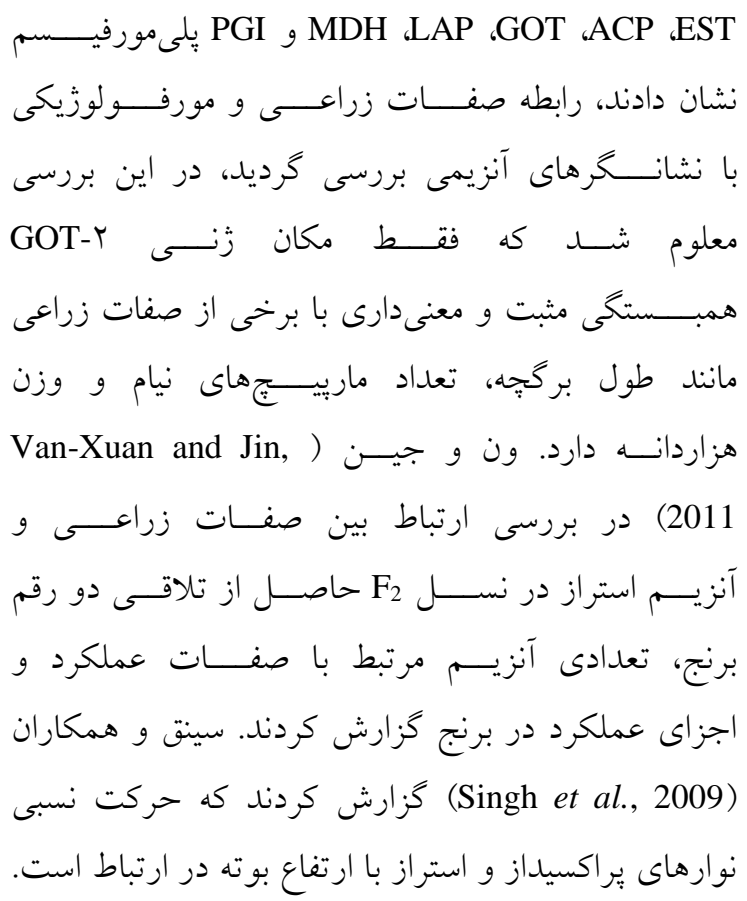

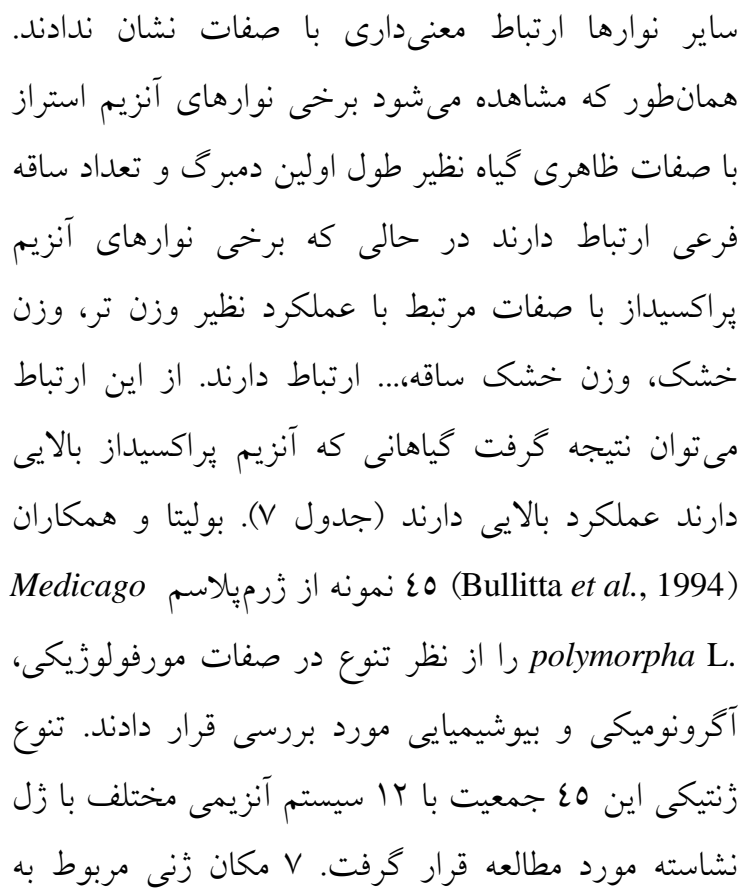

\section{References}

Abdollahi, B. (2013). Study of genetic diversity in some populations of cultivated alfalfa (Medicago sativa L.) using morphological traits. Modern Genetic, 7: 381-388 (In Persian).

Bouton, J. (1982). Seedling characteristics to predict yield and total $\mathrm{N}$ of mature alfalfa plants. Crop Science, 22: 128-130.

Bullitta, S., Floris, R., Hayward, M., Loi, A., Porqueddu, C. and Veronesi, F. (1994). Morphological and biochemical variation in Sardinian populations of Medicago polymorpha L. suitable for rainfed Mediterranean conditions. Euphytica, 77: 263-268.

Clegg, M. (1997). Plant Genetic Diversity and the Struggel to Measure Selection. Journal of Heredity, 88: $1-7$.

Corts, M.M. and Martinez, M.C. (2000). Variation of PGM and IDH isozymes for identification of alfalfa varieties. Euphytica, 112: 137-143.

Hartl, D.L. and Clark, A.G. (1989). Principles of population genetics, $2^{\text {nd }}$ edn, Sinauer associates, Massachusetts, USA.

Hedrick, P.W. (2005). Genetics of populations, $3^{\text {th }}$ edn, Jones and Bartlett Publishers, Massachusetts, USA.

Kaljund, K. and Jaaska, V. (2010). No loss of genetic diversity in small and isolated populations of "Medicago sativa "subsp. falcata". Biochemical Systematics and Ecology, 38: 510-520.

Labdi, M., Robertson, L., Singh, K. and Charrier, A. (1996). Genetic diversity and phylogenetic relationships among the annual Cicer species as revealed by isozyme polymorphism. Euphytica, 88: $181-188$.

Lamkey, K. and Lee, M. (1993). Quantitative genetics, molecular markers, and plant improvement. Paper presented at the Focused plant improvement: Towards responsible and sustainable agriculture Proc $10^{\text {th }}$ Australian Plant Breeding Conf, Gold Coast.

McCoy, T.J. and Bingham, E.T. (1988). Cytology and cytogenetics of alfalfa In: Alfalfa and Alfalfa improvement (Hanson, A., Barnes, D. and Hill, R., Eds.) pp. 737-776, Agron, Monograph 29, Madison, USA.

Mengoni, A., Gori, A. and Bazzicalupo, M. (2000). Use of RAPD and microsatellite (SSR) variation to assess genetic relationships among populations of tetraploid alfalfa, Medicago sativa. Plant Breeding, 119: 311-317. 
Michaud, R., Lehman, W. and Rumbaugh, M. (1988). World distribution and historical development In: Alfalfa and alfalfa improvement (Hanson, A., Barnes, D. and Hill, R., Eds.) pp. 25-91, Agron, Monograph 29, Madison, USA.

Nei, M. (1973). Analysis of gene diversity in subdivided populations. Proceedings of the National Academy of Sciences, 70: 3321-3323.

Oleson, B. (1994). World wheat production, utilization and trade In: Wheat Production, Properties and Quality (Bushuk, W. and Rasper, V. F., Eds.) pp. 1-11, Springer, Chapman and Hall, London, UK.

Quiros, C.F. (1980). Identification of alfalfa plants by enzyme electrophoresis. Crop science, 20: 262264.

Simons, R. (1990). Relationships between seedling traits and mature plant yield in alfalfa. Canadian Journal of Plant Science, 69: 206-213.

Singh, A.K., Mishra, A. and Shukla, A. (2009). Genetic assessment of traits and genetic relationship in blackgram (Vigna mungo) revealed by isoenzymes. Biochemical Genetics, 47: 471-485.

Soltis, D.E. and Soltis, P.S. (1990). Isozymes in plant biology, Springer, Chapman and Hall, London, UK.

Tucak, M., Popovic, S., Cupic, T., Grljusic, S., Bolaric, S. and Kozumplik, V. (2008). Genetic diversity of alfalfa (Medicago spp.) estimated by molecular markers and morphological characters. Periodicum Biologorum, 110: 243-249.

Valizadeh, M., Mohayeji, M., Yasinzadeh, N., Nasrullazadeh, S. and Moghadam, M. (2011). Genetic diversity of synthetic alfalfa generations and cultivars using tetrasomic inherited allozyme markers. Journal of Agricultural Science and Technology, 13: 425-430.

Van-Xuan, D. and Jin, I.D. (2011). Relationship between esterase isozymes and some agronomic traits in F2 populations derived from the crossing of Milyang 23 and Ashahi. Journal of Crop Science and Biotechnology, 14: 11-15.

Veronesi, F., Brummer, E.C. and Huyghe, C. (2010). Alfalfa In: Handbook of plant breeding: Fodder Crops and Amenity Grasses (Boller, B., Posselt, U.K. and Veronesi, F., Eds.) pp. 395-437, Springer, New York, USA.

Veronesi, F., Rosellini, D. and Albertini, E. (2003). The use of molecular markers in alfalfa breeding. Czech Journal of Genetics and Plant Breeding, 39: 104-111.

Xie, C. and Mosjidis, J. (1995). Seedling-selection effects on morphological traits of mature plants in red clover. Theoretical and Applied Genetics, 91: 1032-1036.

Yeh, F., Yang, R. and Boyle, T. (1999). POPGENE VERSION 1.31: Microsoft Window-based Freeware for Population Genetic Analysis, University of Alberta. Edmonton Journal, AB, Canada.

Zeidler, M. (2000). Electrophoretic analysis of plant isozymes. Biologica, 38: 7-16. 


\title{
Investigation of Esterase and Peroxidase Isozymes in Improved and Iranian Landraces of Alfalfa and Their Relationships with Agronomic and Morphological Traits
}

\author{
Maryam Ahmadi', Mustafa Valizadeh,", Mahmoud Tourchi², Mohammad Moghaddam \\ Vahed $^{2}$ and Hossein Mohammadzadeh Jalaly ${ }^{1}$ \\ 1- Former M.Sc. Student, Department of Plant Breeding and Biotechnology, Agriculture \\ Faculty, University of Tabriz, Tabriz \\ 2- Professor, Department of Plant Breeding and Biotechnology, Agriculture Faculty, \\ University of Tabriz, Tabriz
}

(Received: December 26, 2013 - Accepted: March 15, 2014)

\begin{abstract}
For evaluation of genetic diversity among improved alfalfa varieties and Iranian landraces, 12 populations including five improved varieties (Kaysari, Kadi, Ranger, Mesmir, Seariver) and seven landraces (Gharayonje, Amozeynadin, Rahnani, Tazekand, Shazand, Hamedani, Yazdi) were evaluated using agronomic traits and enzyme markers. Thirty-five individuals of each variety were grown and analyzed in separate pots in a unbalanced completely randomized design (CRD). Analysis of variance for agronomic traits showed significant differences for most of the traits among improved and landrace varieties. For esterase and peroxidase enzymes based on presence or absence of enzyme bands $(1,0)$ eleven polymprphic isozyme bands were detected. For improved and landrace varieties Shanon index mean was $0.48 \pm 0.246$ and $0.519 \pm 0.193$, respectively, furthermore Nei genetic diversity index mean for improved and landraces was $0.327 \pm 0.181$ and $0.352 \pm 0.148$ respectively, suggesting no difference between improved and landrace varieties was found. Analysis of relation between isozyme markers and agronomic traits showed that there are significant differences between the presence of POX-4 and wet and dry yield in improved varieties.
\end{abstract}

Keywords: Alfalfa, Genetic diversity, Isozyme markers, Polymorphism.

\footnotetext{
* Corresponding Author, E-mail: mvalizadeh@tabrizu.ac.ir
} 